\title{
Awareness and Acceptance of COVID-19 Vaccines among Pharmacy Students in Zambia: The Implications for Addressing Vaccine Hesitancy
}

Steward Mudenda ( $\nabla$ freshsteward@gmail.com )

University of Zambia https://orcid.org/0000-0003-1692-8981

Moses Mukosha

University of Zambia

Johanna Catharina Meyer

Sefako Makgatho Health Sciences University, Pretoria, South Africa

Joseph Fadare

Ekiti State University, Ado-Ekiti, Nigeria

\section{Brian Godman}

University of Strathclyde, Glasgow G4 ORE, United Kingdom

Martin Kampamba

University of Zambia

Aubrey Chichonyi Kalungia

University of Zambia

Sody Munsaka

University of Zambia

Roland Nnaemeka Okoro

University of Maiduguri, Nigeria

Victor Daka

9Copperbelt University

Misheck Chileshe

MaryBegg Health Services

Ruth Lindizyani Mfune

Copperbelt University

Webrod Mufwambi

University of Zambia

Christabel Nangandu Hikaambo

University of Zambia 
Keywords: Awareness, Acceptability, COVID-19 vaccines, Hesitancy, Pharmacy Students, Vaccination, Zambia

Posted Date: June 24th, 2021

DOI: https://doi.org/10.21203/rs.3.rs-651501/v1

License: (1) This work is licensed under a Creative Commons Attribution 4.0 International License. Read Full License 


\section{Abstract}

Background: Several vaccines have been developed and administered since coronavirus disease 2019 (COVID-19) was declared a pandemic in March 2020. In April 2021, the authorities in Zambia administered the first doses of the Oxford-AstraZeneca ${ }^{\circledR}$ COVID-19 vaccine. However, little is known about the awareness and acceptability of the vaccines among the Zambian population. This study was undertaken to address this starting with undergraduate pharmacy students in Zambia.

Materials and methods: A descriptive cross-sectional survey was conducted among 326 undergraduate pharmacy students in Zambia using an online semi-structured questionnaire from 12th to 25th April 2021 and analysed using Stata version 16. Test of associations were undertaken using Pearson chi-square test or Fisher's exact test as appropriate. The multivariable logistic regression was used to investigate the determinants of awareness and acceptability. All statistical tests were performed at a $5 \%$ significance level and 95\% confidence level.

Results: Among 326 participants, $98.8 \%$ were aware of the COVID-19 vaccination programme but only $24.5 \%$ would accept the vaccine should it be made available to them. Awareness of the COVID-19 vaccine was influenced by religious beliefs ( $\mathrm{aOR}=0.01,95 \% \mathrm{Cl}: 0.01$ to $0.20, \mathrm{p}=0.004)$. Being male $(\mathrm{aOR}=1.78,95 \%$ Cl: 1.05 to $3.02, p=0.034)$ and single $(a O R=2.61,95 \% \mathrm{Cl}: 1.04$ to $6.55, p=0.041)$ was associated with higher odds of accepting the vaccine. Being unemployed (aOR=0.31, 95\% $\mathrm{Cl}: 0.15$ to $0.66, p=0.002$ ) was associated with lower odds of vaccine acceptancy. Barriers to acceptance of the vaccine were possible side effects (78.5\%) and scepticism about its effectiveness to prevent COVID-19 (10.2\%).

Conclusion: There was significant vaccine hesitancy towards COVID-19 vaccines among Zambian pharmacy students despite their awareness about the vaccines. Health authorities must work collaboratively with the Universities and other institutions to mitigate vaccine hesitancy, especially with pharmacy students a key part of the future healthcare workforce overseeing disease prevention strategies. These findings can help guide future interventions to address vaccine hesitancy to reduce future transmission rates of this virus.

\section{Background}

The novel coronavirus disease 2019 (COVID-19), caused by severe acute respiratory syndrome coronavirus 2 (SARS-CoV-2), was first reported in late 2019 in Wuhan City, China (1, 2). Subsequently declared a pandemic by the World Health Organization (WHO) on 11 March 2020 (3-5) and spread rapidly across the globe bringing appreciable socioeconomic disruption alongside increased morbidity and mortality (6-11). 
Despite the initial containment of the pandemic in several countries including African and Asian countries through lockdowns and other measures including social distancing, the mandatory wearing of personal protective equipment (PPE), promoting regular hand hygiene, closure of borders and mass testing (12-18), infection rates continue to increase (19). Alongside this, we have seen the rise in morbidity and mortality from other diseases, including non-communicable diseases (NCDs) as a result of lockdown and other measures (20-23). Alongside this, Abbas et al. (2020) recently calculated that across Africa for every one excess death due to COVID-19, continuing with routine vaccination as opposed to lockdown measures could have prevented 84 deaths in children due to infectious diseases including diphtheria, hepatitis B, Haemophilus influenzae type b, measles, meningitis, Streptococcus pneumoniae, rotavirus, tetanus, and yellow fever (24). We are also aware that there has been an appreciable increase in the prescribing and dispensing of antibiotics for patients with COVID-19 despite only a limited number of patients having underlying bacterial infections driving up antimicrobial resistance (AMR) rates (25-28). However, this is not universal with limited increases in the self-purchasing of antibiotics to treat COVID 19 among African and Asian countries with trained pharmacists available as well as legislation being followed $(13,16,29)$.

These concerns with the unintended consequences of COVID-19, coupled with the socioeconomic consequences of COVID-19 along with growing morbidity and mortality rates, has resulted in pharmaceutical companies, governments, funding agencies worldwide investing considerable efforts and resources in accelerated research and development of vaccines as a viable future prevention measure once the gene sequence became known (30-34). As of 16 June 2021, there were 287 vaccine candidates, 185 in the pre-clinical phase and 102 in the clinical phase (35). In addition, 22 candidates had been submitted to the WHO for emergency use validation of which 7 had been approved to date (36). This built on 291 candidates available as of January 262021 in the tracker organised by the London School of Hygiene and Tropical Medicine (37). However, whilst appreciable progress has been made with vaccination programmes especially among high-income countries, there are still significant challenges. A key challenge is the uncertainty about the acceptance of COVID-19 vaccination among healthcare workers and the public across countries (38-43), with vaccine hesitancy fuelled by certain social media activities (44-46). For any immunization program to be successful, acceptance of the vaccine is critical and mirrors the general awareness of disease risk, vaccine attitudes and demand for vaccination within the general population $(25,47-49)$.

We have seen vaccine hesitancy, defined as 'delay in acceptance or refusal of vaccination despite the availability of vaccination services in other situations across countries (50-63). Similar variable hesitancy rates have been reported regarding the acceptance of the COVID-19 vaccine $(46,63-66)$. In his systematic review, Sallam (2021) found low acceptance rates in Kuwait (23.6\%) and Jordan (28.4\%) versus appreciably higher acceptance rates in China (91.3\%), Indonesia (93.3\%) and Malaysia (94.3\%) (66). Lazarus et al (2021) in their global survey also found variable acceptance rates (65). Other authors also 
found low acceptance rates in Egypt (21\%) (67), the Democratic Republic of Congo (27.7\%) (38), Uganda $(37.3 \%)$ (68)and Jordan (37.4\%) (69). This is likely linked to considerable misinformation regarding the vaccine including data on its effectiveness and safety fuelled, as mentioned, via social media and other activities including conspiracy theories $(41,42,44,45)$. In addition, issues of importance for the vaccine (62). This is similar to the misinformation that has existed for potential treatments for COVID-19 including hydroxychloroquine and the subsequent impact on morbidity, mortality and costs $(13,14,70$ 73).

Whilst to date, the morbidity and mortality from COVID-19 appears lower among African countries compared with higher-income countries (12), in Zambia, as of 22 June 2021, there have been 133,659 confirmed cases of COVID-19 with 1,744 deaths and 148,304 vaccine doses have been administered (74). It is hoped that the nationwide programme will accelerate with the recent approval of five vaccines in Zambia building on the WHO's Emergency Use listing of the vaccines (75). Given the concerns with hesitancy surrounding the COVID-19 vaccine across countries (66), we believe there is an urgent need to describe and understand vaccine acceptance levels among the population in Zambia. Subsequently, use the findings to instigate activities to address this building on experiences across countries $(44,50,66)$.

Since healthcare workers ( $\mathrm{HCWs)} \mathrm{across} \mathrm{countries} \mathrm{are} \mathrm{heavily} \mathrm{involved} \mathrm{in} \mathrm{the} \mathrm{vaccination} \mathrm{programme}$ and have typically been prioritized initially for the COVID-19 vaccine, we believed it was necessary to ascertain vaccine awareness and acceptance in this priority group. We started by assessing vaccine awareness and acceptance among pharmacists as they play a key role in any pandemic offering advice to patients regarding ways to reduce transmission and potential treatments as well as increasingly administrating vaccines $(16,76-79)$. This started with undergraduate pharmacy students as they are the future pharmacists and custodians of medicines and vaccine development. We also aimed to identify barriers that may influence vaccine acceptance and uptake in Zambia in the future. The findings should help develop a working hypothesis for more extensive interventions to improve future vaccination rates in Zambia if concerns were identified.

\section{Materials And Methods}

\subsection{Study design and target population}

We conducted an online cross-sectional study using a self-administered questionnaire to ensure compliance with current public health guidelines such as social distancing and minimal person-to-person interactions. We invited 632 undergraduate pharmacy students enrolled in the pharmacy degree programme from the University of Zambia (UNZA), Lusaka Apex Medical University (LAMU) and Mulungushi University (MU) to participate. 
Many students were invited via social media profiles (WhatsApp and Facebook). Consequently, the online questionnaire was made available on Google Forms from $12^{\text {th }}$ to $25^{\text {th }}$ April 2021, during the period when Zambia just started the administration of the Oxford/ AstraZeneca vaccine. Questionnaires were sent to eligible students identified by university registers. To increase participation, reminders were sent twice a week for those who did not respond for three consecutive weeks.

\subsection{Sample size calculation}

Prior to conducting the study, a representative sample size of the population was calculated using Yamane's formula; $n=(80)$. A margin of error of $5 \%$ and a population of 632 were used. A $10 \%$ loss or non-response was anticipated. This resulted in a minimum of 259 study participants.

\subsection{Data Collection Tool}

A validated questionnaire was adapted from recent studies regarding COVID-19 vaccine acceptability across countries $(38,67,81)$. The questionnaire was first circulated to experts from the University of Zambia and Copperbelt University to allow for content and face validation. The modified questionnaire was subsequently pre-tested on 20 pharmacy students at UNZA, who, later were excluded from the main study. We added questions on awareness and removed the questions on attitude and perceptions as our study did not focus on these two aspects.

The adapted questionnaire (Appendix) was used to collect data on socio-demographic characteristics (Section A), awareness (Section B) and acceptability (Section C) of COVID-19 vaccines among pharmacy students in Zambia. Section B contained questions on awareness of the COVID-19 vaccine. Students who scored $50 \%$ and above were grouped as being aware of the COVID-19 vaccines. Section C contained questions on the acceptability of vaccination against the COVID-19 vaccine.

\subsection{Study variables}

The study had two objectives. The first objective was to assess the awareness of COVID-19 among the pharmacy students. The second objective was to determine the acceptability of the COVID-19 vaccine among pharmacy students if made available on the Zambian market. 
For the first objective, we measured awareness scores as a binary variable ( $1=$ aware if scored 50 or more, $0=$ not aware if scored less than 50 ), and for the second objective, we measured vaccine acceptance ( $1=y e s, 0=$ no) based on average scores.

Students who scored $50 \%$ and above were grouped as willing to be vaccinated against COVID-19. For the two objectives, we collected the following determinants: religion measured as Christian, Islam and others, i.e., minor religions in Zambia such as Hinduism and Buddhism, and employment status as pharmacy students in Zambia, i.e., comprising those in employment as pharmacy technologists (holders of a diploma) and those that come directly into the degree programmes from high school. In addition, gender, residential area (rural-urban, rural and urban), heard of the COVID-19 vaccine (yes/no), source of information (Friends/Family, Health workers, Internet, Radio and Television) and age (number of years from the date of last birthday).

Since our study outcomes included ascertaining awareness and acceptability of the COVID-19 vaccine, we also assessed undergraduate students' awareness and acceptability of vaccination against COVID- 19 .

\subsection{Data Analysis}

Stata/IC version 16 (Stata Corp., College Station, Texas, USA) was used for statistical analysis. Descriptive analysis was done on the socio-demographic characteristics of participants. Categorical variables were expressed as frequencies and percentages. Association between demographic variables and outcomes of interest were done using the Pearson chi-square test or Fisher's exact test as appropriate.

Bivariate logistic regression was fitted to obtain crude estimates (results not shown) for the two outcomes, awareness (yes $=1$, no $=0$ ) and acceptability ( $y e s=1, n o=0$ ). Separate multivariable logistic regression models were fitted for the two outcomes, including only variables with a $p<0.20$ from the bivariate analysis to adjust for confounders. The multivariable regression models were fitted using stepwise regression and backward elimination algorithms with a liberal $p$-value for exclusion $(p=0.20)$. Interactions were investigated, and none was found to approach statistical significance. Hosmer-Lemeshow goodness-of-fit test was used to assess the predictive ability of the model. All statistical tests were done at a $5 \%$ significance level and $95 \%$ confidence level.

\subsection{Ethical approval}


The study protocol was approved by the University of Zambia Health Sciences Research Ethics Committee (UNZAHSREC) and the Zambia National Health Research Authority (NHRA). The study was approved under the protocol ID: 20190217024, IORG no: 0009227, IRB no: 00011000. All participants were aware of the objectives of the study and provided informed consent by reading and responding to the online survey.

\section{Results}

\subsection{General including sociodemographic characteristics}

A total of 326 undergaduate pharmacy students out of the invited 632 students completed the questionnaire thereby giving a response rate of $52 \%$. The sociodemographic characteristics of respondents according to awareness and acceptability of COVID-19 vaccination are shown in Table 1.

The internet was the principal source of information for all respondents who were aware of COVID-19 vaccines. Having heard of COVID-19 $(p=0.012)$ and religion status $(p=0.048)$ were significantly associated with awareness scores. Overall, awareness of COVID-19 among participants was $98.77 \%(\mathrm{n}=$ 322).

Table 1: Sociodemographic characteristics of the participants according to their awareness of COVID-19 vaccination 


\begin{tabular}{|c|c|c|c|c|c|}
\hline Characteristic & Category & $\begin{array}{c}\text { Total } \\
\text { population } \\
\text { N (\%) }\end{array}$ & $\begin{array}{c}\text { Awareness } \\
(<50 \% \\
\text { score) } \\
\text { N (\%) }\end{array}$ & $\begin{array}{c}\text { Awareness } \\
(\geq 50 \% \text { score) } \\
\text { N (\%) }\end{array}$ & $\begin{array}{c}P- \\
\text { value }^{\mathrm{a}}\end{array}$ \\
\hline Age (years) & $\begin{array}{c}18-23 \\
24-29 \\
30-35 \\
36-41 \\
>41\end{array}$ & $\begin{array}{c}157(48.16) \\
110(33.74) \\
38(11.66) \\
16(4.91) \\
5(1.53)\end{array}$ & $\begin{array}{c}3(75.00) \\
1(25.00) \\
0 \\
0 \\
0\end{array}$ & $\begin{array}{c}154(47.83) \\
109(33.85) \\
38(11.80) \\
16(4.97) \\
5(1.55)\end{array}$ & 0.841 \\
\hline Gender & $\begin{array}{c}\text { Female } \\
\text { Male }\end{array}$ & $\begin{array}{l}162(49.69) \\
164(50.31)\end{array}$ & $\begin{array}{l}1(25.00) \\
3(75.00)\end{array}$ & $\begin{array}{l}161(50.00) \\
161(50.00)\end{array}$ & 0.623 \\
\hline Marital status & $\begin{array}{l}\text { Married } \\
\text { Single }\end{array}$ & $\begin{array}{c}55(16.87) \\
271(83.13)\end{array}$ & $\begin{array}{c}0 \\
4(100)\end{array}$ & $\begin{array}{l}55(17.08) \\
267(82.92)\end{array}$ & 1.000 \\
\hline Religion & $\begin{array}{c}\text { Christianity } \\
\text { Islam } \\
\text { Others }\end{array}$ & $\begin{array}{c}322(98.77) \\
2(0.61) \\
2(0.61)\end{array}$ & $\begin{array}{c}3(75.00) \\
0 \\
1(25.00)\end{array}$ & $\begin{array}{c}319(99.07) \\
2(0.62) \\
1(0.31)\end{array}$ & 0.048 \\
\hline Employment & $\begin{array}{l}\text { Yes } \\
\text { No }\end{array}$ & $\begin{array}{c}86(26.38) \\
240(73.62)\end{array}$ & $\begin{array}{c}0 \\
4(100)\end{array}$ & $\begin{array}{l}86(26.71) \\
236(73.29)\end{array}$ & 0.292 \\
\hline Residential area & $\begin{array}{c}\text { Rural-Urban } \\
\text { Rural } \\
\text { Urban }\end{array}$ & $\begin{array}{c}64(19.63) \\
35(10.74) \\
227(69.63)\end{array}$ & $\begin{array}{l}1(25.00) \\
1(25.00) \\
2(50.00)\end{array}$ & $\begin{array}{c}63(19.57) \\
34(10.56) \\
225(69.88)\end{array}$ & 0.355 \\
\hline $\begin{array}{l}\text { Heard of the COVID-19 } \\
\text { vaccine }\end{array}$ & $\begin{array}{l}\text { No } \\
\text { Yes }\end{array}$ & $\begin{array}{c}1(0.31) \\
325(99.69)\end{array}$ & $\begin{array}{l}1(25.00) \\
3(75.00)\end{array}$ & $\begin{array}{c}0 \\
322(100)\end{array}$ & 0.012 \\
\hline Source of information & $\begin{array}{c}\text { Friends/family } \\
\text { Health } \\
\text { workers } \\
\text { Internet } \\
\text { Radio } \\
\text { Television }\end{array}$ & $\begin{array}{c}5(1.53) \\
29(8.90) \\
159(48.77) \\
4(1.23) \\
129(39.57)\end{array}$ & $\begin{array}{c}0 \\
1(25.00) \\
3(75.00) \\
0 \\
0\end{array}$ & $\begin{array}{c}5(1.55) \\
28(8.70) \\
156(48.45) \\
4(1.24) \\
129(40.06)\end{array}$ & 0.232 \\
\hline Overall & & $\mathrm{N}=326$ & $(\mathrm{~N}=4) 1.23 \%$ & $\begin{array}{c}(\mathrm{N}=322) \\
98.77 \%\end{array}$ & \\
\hline
\end{tabular}

Key: ${ }^{\mathrm{a}=}$ Fisher's exact test

The sociodemographic characteristics of the participants according to their COVID-19 vaccine acceptability are shown in Table 2. There was evidence of an association between acceptability and employment status $(p=0.044)$ and the gender of participants $(\mathrm{p}=0.024)$. The overall acceptability of the COVID-19 vaccination among participants was $24.54 \%(n=80)$.

Table 2: Sociodemographic characteristics of the participants according to their acceptability of the COVID-19 vaccine 


\begin{tabular}{|c|c|c|c|c|c|}
\hline Characteristic & Category & $\begin{array}{c}\text { Total } \\
\text { population } \\
\text { N (\%) }\end{array}$ & $\begin{array}{c}\text { Acceptability ( }<50 \% \\
\text { score) }\end{array}$ & $\begin{array}{c}\text { Acceptability }(\geq 50 \% \\
\text { score) }\end{array}$ & $\begin{array}{c}P- \\
\text { value }\end{array}$ \\
\hline Age (years) & $\begin{array}{c}18-23 \\
24-29 \\
30-35 \\
36-41 \\
>41\end{array}$ & $\begin{array}{c}157(48.16) \\
110(33.74) \\
38(11.66) \\
16(4.91) \\
5(1.53)\end{array}$ & $\begin{array}{c}123(50.81) \\
82(33.33) \\
24(9.76) \\
11(4.47) \\
4(1.63)\end{array}$ & $\begin{array}{c}32(40.00) \\
28(35.00) \\
14(17.50) \\
5(6.25) \\
1(1.25)\end{array}$ & $0.246^{\mathrm{a}}$ \\
\hline Gender & $\begin{array}{l}\text { Female } \\
\text { Male }\end{array}$ & $\begin{array}{l}162(49.69) \\
164(50.31)\end{array}$ & $\begin{array}{l}131(53.25) \\
115(46.75)\end{array}$ & $\begin{array}{l}31(38.75) \\
49(61.25)\end{array}$ & $0.024^{b}$ \\
\hline Marital status & $\begin{array}{l}\text { Married } \\
\text { Single } \\
\end{array}$ & $\begin{array}{c}55(16.87) \\
271(83.13) \\
\end{array}$ & $\begin{array}{l}41(16.67) \\
205(83.33)\end{array}$ & $\begin{array}{l}14(17.50) \\
66(82.50) \\
\end{array}$ & $0.092^{\mathrm{a}}$ \\
\hline Religion & $\begin{array}{c}\text { Christianity } \\
\text { Islam } \\
\text { Others }\end{array}$ & $\begin{array}{c}322(98.77) \\
2(0.61) \\
2(0.61)\end{array}$ & $\begin{array}{c}244(99.19) \\
2(0.81) \\
0\end{array}$ & $\begin{array}{c}78(97.50) \\
0 \\
2(2.50)\end{array}$ & $0.116^{\mathrm{a}}$ \\
\hline Employment & $\begin{array}{l}\text { Yes } \\
\text { No }\end{array}$ & $\begin{array}{c}86(26.38) \\
240(73.62)\end{array}$ & $\begin{array}{l}58(23.58) \\
188(76.42)\end{array}$ & $\begin{array}{l}28(35.00) \\
52(65.00)\end{array}$ & $0.044^{b}$ \\
\hline Residential area & $\begin{array}{c}\text { Rural-Urban } \\
\text { Rural } \\
\text { Urban }\end{array}$ & $\begin{array}{c}64(19.63) \\
35(10.74) \\
227(69.63)\end{array}$ & $\begin{array}{c}49(19.92) \\
26(10.57) \\
171(69.51)\end{array}$ & $\begin{array}{c}15(18.75) \\
9(11.25) \\
56(70.00)\end{array}$ & $0.966^{\mathrm{b}}$ \\
\hline $\begin{array}{l}\text { Heard of the COVID-19 } \\
\text { vaccine }\end{array}$ & $\begin{array}{l}\text { Yes } \\
\text { No }\end{array}$ & $\begin{array}{c}325(99.69) \\
1(0.31)\end{array}$ & $\begin{array}{c}245(99.59) \\
1(0.41)\end{array}$ & $\begin{array}{c}80(100) \\
0\end{array}$ & $1.000^{\mathrm{a}}$ \\
\hline Source of information & $\begin{array}{c}\text { Friends/family } \\
\text { Health } \\
\text { workers } \\
\text { Internet } \\
\text { Radio } \\
\text { Television } \\
\end{array}$ & $\begin{array}{c}5(1.53) \\
29(8.90) \\
159(48.77) \\
4(1.23) \\
129(39.57)\end{array}$ & $\begin{array}{c}5(2.03) \\
20(8.13) \\
125(50.81) \\
3(1.22) \\
93(37.80)\end{array}$ & $\begin{array}{c}0 \\
9(11.25) \\
34(42.50) \\
1(1.25) \\
36(45.00)\end{array}$ & $0.412^{\mathrm{a}}$ \\
\hline \multicolumn{2}{|l|}{ Overall } & $\mathrm{N}=326$ & $(\mathrm{~N}=246) 75.46 \%$ & $(\mathrm{~N}=80) 24.54 \%$ & \\
\hline
\end{tabular}

Key: ${ }^{a=}$ Fisher's exact test, ${ }^{b}=$ Pearson Chi-square test

\subsection{Factors influencing awareness and acceptability of COVID-19 vaccines}

Being of other religion compared to the Christian faith was associated with reduced odds of awareness of the COVID-19 vaccination (aOR=0.01, 95\% Cl: 0.01 to $0.20, p=0.004$ ) adjusting for gender and residential area (Table 3).

Being unemployed (aOR=0.31, 95\% $\mathrm{Cl}: 0.15$ to $0.66, p=0.002)$ was significantly associated with reduced odds of acceptability of COVID-19 vaccination controlling for the sex of the participant. On the other hand, male gender ( $\mathrm{aOR}=1.78,95 \% \mathrm{Cl}: 1.05$ to $3.02, \mathrm{p}=0.034)$ and being married (aOR=2.61, 95\% Cl: 1.04 to $6.55, p=0.041$ ) was independently associated with increased odds of acceptability of COVID-19 vaccination. 
Table 3: Adjusted Multivariable logistic regression of factors associated with awareness and acceptability of COVID vaccines

\begin{tabular}{|c|c|c|c|c|c|}
\hline Characteristic & Category & $\begin{array}{c}\text { Awareness of COVID- } \\
19 \\
(\geq 50 \% \text { score }) \\
\end{array}$ & & $\begin{array}{c}\text { Acceptability of COVID-19 } \\
\text { vaccine } \\
(\geq 50 \% \text { score })\end{array}$ & \\
\hline & & aOR (95\% CI) & $\begin{array}{c}P \text { - } \\
\text { value }\end{array}$ & aOR $(95 \% \mathrm{CI})$ & $\begin{array}{c}P \text { - } \\
\text { value }\end{array}$ \\
\hline Gender & $\begin{array}{c}\text { Female } \\
\text { Male }\end{array}$ & - & - & $\begin{array}{c}\text { Ref } \\
1.78(1.05-3.02)\end{array}$ & 0.034 \\
\hline Marital status & $\begin{array}{l}\text { Married } \\
\text { Single }\end{array}$ & & & $\begin{array}{c}\text { Ref } \\
2.61(1.04-6.55)\end{array}$ & 0.041 \\
\hline Religion & $\begin{array}{c}\text { Christianity } \\
\text { Islam } \\
\text { Others } \\
\end{array}$ & $\begin{array}{c}\text { Ref } \\
- \\
0.01(0.01-0.20) \\
\end{array}$ & 0.004 & & \\
\hline Employment & $\begin{array}{l}\text { Yes } \\
\text { No }\end{array}$ & & & $\begin{array}{c}\text { Ref } \\
0.31(0.15-0.66)\end{array}$ & 0.002 \\
\hline $\begin{array}{l}\text { Residential } \\
\text { area }\end{array}$ & $\begin{array}{l}\text { Rural- } \\
\text { Urban } \\
\text { Rural } \\
\text { Urban }\end{array}$ & $\begin{array}{c}\text { Ref } \\
0.54(0.03-8.92) \\
3.36(0.20-55.36)\end{array}$ & $\begin{array}{l}0.666 \\
0.397\end{array}$ & & \\
\hline
\end{tabular}

Key: aOR-adjusted odds ratios, 95\% CI-95\% confidence intervals, Students of pharmacy with a diploma are in employment except for direct entrants into the degree program. On category others, we included all minor religions in Zambia (i.e., Hinduism, Buddhism etc). Acceptability was measured as having scores of 50 or more, Awareness was measured as having scores of 50 or more

\section{Reasons for student's refusal to be vaccinated against COVID-19}

Out of the 246 participants who were hesitant to receive the COVID-19 vaccine, the majority (78.5\%) were concerned about the possible adverse effects of COVID-19 vaccines (Table 4). Similarly, 71.1\% felt that the COVID-19 vaccines did not pass through all the stages of clinical trials, hence, their concerns with safety issues.

Table 4: Hesitancy_against COVID-19 vaccination among_pharmacy students 


\begin{tabular}{|l|c|c|}
\hline Reasons for refusing vaccination & $\begin{array}{c}\text { Frequency } \\
\text { (n) }\end{array}$ & $\begin{array}{c}\text { Percent } \\
\text { (\%) }\end{array}$ \\
\hline I would be hesitant to be vaccinated because & 25 & 10.2 \\
\hline COVID-19 vaccines are not effective & 193 & 78.5 \\
\hline I am concerned about the safety of COVID-19 vaccines & 28 & 11.4 \\
\hline I do not need the COVID-19 vaccine & 246 & 100 \\
\hline Total & & \\
\hline Do you think COVID-19 vaccines have passed through all stages of clinical trials to \\
ensure their safety? & 58 & 23.6 \\
\hline I don't know & 175 & 71.1 \\
\hline No & 13 & 5.3 \\
\hline Yes & 246 & 100 \\
\hline Total & & \\
\hline
\end{tabular}

\section{Discussion}

We believe this is the first study conducted in Zambia to explore the awareness and acceptability of the COVID-19 vaccines among undergraduate pharmacy students.

Encouragingly, we found a high awareness rate of $98.8 \%$ for COVID-19 vaccines, similar to medical students in Uganda (98.3\%) (68) and the Democratic Republic of Congo (99.3\%) (38). This could be attributed to awareness campaigns and information available on news and social media with the students reporting the internet $(48.77 \%)$, television $(39.75 \%$ and $\mathrm{HCWs}(8.90 \%)$ as their main sources of information about COVID-19 vaccines. This is different though to the US where the main source of information leading to increased awareness of the COVID-19 vaccine were the health agencies in addition to mass media (82).

However, the low acceptance rate for the COVID-19 vaccine at $24.5 \%$ among our pharmacy undergraduates is a concern. This though is similar to low rates of $29.4 \%$ among the public in Jordan, Kuwait and Saudi Arabia (42), 34.9\% among university students in Jordan (43) and 37.3\% among medical students in Uganda (68). This compares with appreciably higher rates of $73 \%$ to $77 \%$ among medical students in the US $(83,84), 76.3 \%$ among college students in China (81), 86.1\% among university students in Italy (85), and $91.99 \%$ among medical students in Poland (86). Poland's high acceptability may well be because the medical students in the study were fearful of contracting the virus and spreading it to their family and friends (86). We have also seen variable rates of vaccine acceptance among $\mathrm{HCW}$ s and others across countries. These range from low acceptance rates of $21 \%$ in Egypt (67), $23.4 \%$ in Taiwan (87), and 27.7\% in the Democratic Republic of Congo (38), similar to the students in our study, up to $55 \%$ in Russia (65), $71 \%$ in South Africa, $78.1 \%$ in Israel (66), $78.5 \%$ in Greece (88) and nearly $90 \%$ in China (65). 
Those who were married and those who were not in employment were less likely to accept the COVID-19 vaccine in our study, while male students were more likely to fearful to accept the vaccine. Other studies have also reported similar gender differences in hesitancy rates for the COVID-19 and other vaccines (38, $65,66,89,90)$. We are not sure of the reasons behind this difference in our study. This may be due to male participants having a high-risk perception of diseases compared to females, hence a greater willingness to be vaccinated. However, further research is needed before we can make any definitive statements. The higher acceptance rate among employed personnel may be due to their employers recommending vaccination. Other studies have also reported that vaccine acceptability is affected by some factors including sociodemographics (65).

Vaccine safety and effectiveness were the main reasons for vaccine hesitancy among our students, similar to students and HCWs in other countries $(64,67,68,91)$. This includes concerns that the COVID19 vaccines had not passed through all clinical trial stages to assure safety and effectiveness. The higher rate of vaccine hesitancy seen in our study could also potentially be attributed to adverse reports in social media, conspiracy beliefs and lack of awareness campaigns generally concerning the effectiveness and safety of the different COVID-19 vaccines $(44,68,83,86)$. Interestingly, our recent findings in Zambia are similar to an earlier study in Zambia which documented fear of adverse effects, lack of information on the benefits of vaccines, as well as other beliefs including traditional beliefs as barriers to accessing vaccines (92).

We are aware this study has some limitations. Since the study was limited to pharmacy undergraduate students in Zambia, its results cannot be generalised to students of other healthcare and non-healthcare programmes. Besides, the online nature of the study may have excluded some students because of lack of internet access which may have biased the findings. Despite this, we believe the findings are robust providing direction for the future.

\section{Conclusion}

There was a high level of awareness about COVID-19 vaccines among Zambian pharmacy students in this study. In contrast, their acceptability of having the vaccine was low due to some issues including concerns with the safety and efficacy of the COVID-19 vaccines. Consequently, stakeholders in the healthcare sector need to develop strategies to reassure the populace of the safety and efficacy as well as the success story of COVID-19 vaccination. We also believe there is a critical role for the educators in Pharmacy and Medical schools in Zambia and across Africa to reduce the level of misinformation regarding COVID-19 vaccines, similar to general myths surrounding COVID-19 and its treatment. We will be following this up especially given the pivotal role of community pharmacists during any pandemic.

\section{Declarations}

\section{Declarations of interest}


None

\section{Funding}

This research did not receive any specific grant from funding agencies in the public, commercial, or notfor-profit sectors.

\section{Author contributions}

SM conceptualized the study. SM, CNH, MK and WM participated in data collection. SM and MM conducted data analysis. All authors participated in the draft of the initial manuscript. All authors participated in reviewing the intellectual content of the manuscript. All authors approved the final version of the manuscript.

\section{Acknowledgements}

The authors are grateful to the University of Zambia for providing access to many articles used in this pilot study. We would like to acknowledge the pharmacy students in Zambia for taking part in this study. SM would like to acknowledge that some of his time dedicated to conducting research is supported by the University of Zambia in collaboration with the Africa Centre of Excellence for Infectious Diseases of Humans and Animals (ACEIDHA). MM would like to acknowledge that some of his time is supported by the UNC-UNZA-Wits Partnership for HIV and Women's Reproductive Health (grant number: D43 TW010558).

\section{References}

1. Morens DM, Breman JG, Calisher CH, Doherty PC, Hahn BH, Keusch GT, et al. The Origin of COVID19 and Why It Matters. Am J Trop Med Hyg. 2020;103(3):955-9.

2. World Health Orgnisation. Novel Coronavirus (2019-nCoV) SITUATION REPORT - 121 JANUARY 2020. Available at URL: https://www.who.int/docs/default-source/coronaviruse/situationreports/20200121-sitrep-1-2019-ncov.pdf.

3. Cucinotta D, Vanelli M. WHO Declares COVID-19 a Pandemic. Acta bio-medica : Atenei Parmensis. 2020;91(1):157-60.

4. Sohrabi C, Alsafi Z, O'Neill N, Khan M, Kerwan A, Al-Jabir A, et al. World Health Organization declares global emergency: A review of the 2019 novel coronavirus (COVID-19). International journal of 
surgery. 2020;76:71-6.

5. Shah SGS, Farrow A. A commentary on "World Health Organization declares global emergency: A review of the 2019 novel Coronavirus (COVID-19)". International journal of surgery. 2020;76:128-9.

6. Rasul G, Nepal AK, Hussain A, Maharjan A, Joshi S, Lama A, et al. Socio-Economic Implications of COVID-19 Pandemic in South Asia: Emerging Risks and Growing Challenges. Frontiers in sociology. 2021;6:629693.

7. Nicola M, Alsafi Z, Sohrabi C, Kerwan A, Al-Jabir A, losifidis C, et al. The socio-economic implications of the coronavirus pandemic (COVID-19): A review. International journal of surgery. 2020;78:185-93.

8. O'Driscoll M, Ribeiro Dos Santos G, Wang L, Cummings DAT, Azman AS, Paireau J, et al. Agespecific mortality and immunity patterns of SARS-CoV-2. Nature. 2021;590(7844):140-5.

9. Garrigues E, Janvier P, Kherabi Y, Le Bot A, Hamon A, Gouze H, et al. Post-discharge persistent symptoms and health-related quality of life after hospitalization for COVID-19. The Journal of infection. 2020;81(6):e4-e6.

10. Wang F, Kream RM, Stefano GB. Long-Term Respiratory and Neurological Sequelae of COVID-19. Medical science monitor. 2020;26:e928996.

11. Vasishtha G, Mohanty SK, Mishra US, Dubey M, Sahoo U. Impact of COVID-19 infection on life expectancy, premature mortality, and DALY in Maharashtra, India. BMC Infect Dis. 2021;21(1):343.

12. Ogunleye OO, Basu D, Mueller D, Sneddon J, Seaton RA, Yinka-Ogunleye AF, et al. Response to the Novel Corona Virus (COVID-19) Pandemic Across Africa: Successes, Challenges, and Implications for the Future. Frontiers in pharmacology. 2020;11(1205).

13. Godman B, Haque M, Islam S, Iqbal S, Urmi UL, Kamal ZM, et al. Rapid Assessment of Price Instability and Paucity of Medicines and Protection for COVID-19 Across Asia: Findings and Public Health Implications for the Future. Frontiers in Public Health. 2020;8(744).

14. Sefah I, Ogunleye O, Essah D, Opanga S, Rizvi N, Wamaitha A, et al. Rapid assessment of the potential paucity and price increases for suggested medicines and protection equipment for COVID-19 across developing countries with a particular focus on Africa and the implications. Frontiers in pharmacology. 2021;11(2055).

15. Afriyie DK, Asare GA, Amponsah SK, Godman B. COVID-19 pandemic in resource-poor countries: challenges, experiences and opportunities in Ghana. Journal of infection in developing countries. 2020;14(8):838-43. 
16. Kibuule D, Nambahu L, Sefah IA, Kurdi A, Phuong TNT, Kwon H-Y, Godman B. Activities in Namibia to Limit the Prevalence and Mortality from COVID-19 Including Community Pharmacy Activities and the Implications. Sch Acad J Pharm. 2021; 10(5): 82-92.

17. Kraemer MUG, Yang CH, Gutierrez B, Wu CH, Klein B, Pigott DM, et al. The effect of human mobility and control measures on the COVID-19 epidemic in China. Science. 2020;368(6490):493-7.

18. Ng Y, Li Z, Chua YX, Chaw WL, Zhao Z, Er B, et al. Evaluation of the Effectiveness of Surveillance and Containment Measures for the First 100 Patients with COVID-19 in Singapore - January 2-February 29, 2020. MMWR Morbidity and mortality weekly report. 2020;69(11):307-11.

19. WHO. Weekly epidemiological update on COVID-19 - 8 June 2021. Available at URL: https://www.who.int/publications/m/item/weekly-epidemiological-update-on-covid-19--8-june-2021.

20. Zylke JW, Bauchner H. Mortality and Morbidity: The Measure of a Pandemic. Jama. 2020;324(5):458-9.

21. Kluge HHP, Wickramasinghe K, Rippin HL, Mendes R, Peters DH, Kontsevaya A, et al. Prevention and control of non-communicable diseases in the COVID-19 response. Lancet. 2020;395(10238):1678-80.

22. Azarpazhooh MR, Morovatdar N, Avan A, Phan TG, Divani AA, Yassi N, et al. COVID-19 Pandemic and Burden of Non-Communicable Diseases: An Ecological Study on Data of 185 Countries. Journal of stroke and cerebrovascular diseases: the official journal of National Stroke Association. 2020;29(9):105089.

23. Lim MA, Huang I, Yonas E, Vania R, Pranata R. A wave of non-communicable diseases following the COVID-19 pandemic. Diabetes \& metabolic syndrome. 2020;14(5):979-80.

24. Abbas K, Procter SR, van Zandvoort K, Clark A, Funk S, Mengistu T, et al. Routine childhood immunisation during the COVID-19 pandemic in Africa: a benefit-risk analysis of health benefits versus excess risk of SARS-CoV-2 infection. The Lancet Global health. 2020;8(10):e1264-e72.

25. Godman B, Egwuenu A, Haque M, Malande OO, Schellack N, Kumar S, et al. Strategies to Improve Antimicrobial Utilization with a Special Focus on Developing Countries. Life. 2021;11(6):528.

26. Rawson TM, Moore LSP, Zhu N, Ranganathan N, Skolimowska K, Gilchrist M, et al. Bacterial and Fungal Coinfection in Individuals With Coronavirus: A Rapid Review To Support COVID-19 Antimicrobial Prescribing. Clinical infectious diseases. 2020;71(9):2459-68.

27. Rodríguez-Álvarez M, López-Vidal Y, Soto-Hernández JL, Miranda-Novales MG, Flores-Moreno K, Ponce de León-Rosales S. COVID-19: Clouds Over the Antimicrobial Resistance Landscape. Archives of medical research. 2021;52(1):123-6. 
28. Langford BJ, So M, Raybardhan S, Leung V, Soucy JR, Westwood D, et al. Antibiotic prescribing in patients with COVID-19: rapid review and meta-analysis. Clinical microbiology and infection. 2021;27(4):520-31.

29. Opanga SA, Rizvi N, Wamaitha A, Sefah IA, Godman B. Availability of Medicines in Community Pharmacy to Manage Patients with COVID-19 in Kenya; Pilot Study and Implications. Sch Acad J Pharm. 2021; 10(3): 36-42.

30. Lurie N, Saville M, Hatchett R, Halton J. Developing Covid-19 Vaccines at Pandemic Speed. N Engl J Med. 2020;382(21):1969-73.

31. Jeyanathan M, Afkhami S, Smaill F, Miller MS, Lichty BD, Xing Z. Immunological considerations for COVID-19 vaccine strategies. Nature reviews Immunology. 2020;20(10):615-32.

32. Harapan H, Wagner AL, Yufika A, Winardi W, Anwar S, Gan AK, et al. Acceptance of a COVID-19 Vaccine in Southeast Asia: A Cross-Sectional Study in Indonesia. Front Public Health. 2020;8:381.

33. Graham BS. Rapid COVID-19 vaccine development. Science. 2020;368(6494):945-6.

34. Haque A, Pant AB. Efforts at COVID-19 Vaccine Development: Challenges and Successes. Vaccines. 2020;8(4).

35. WHO. COVID-19 vaccine tracker and landscape. 16 June 2021. Available at URL: https://www.who.int/publications/m/item/draft-landscape-of-covid-19-candidate-vaccines.

36. WHO. Status of COVID-19 Vaccines within WHO EUL-PQ evaluation process. Available at URL: https://extranet.who.int/pqweb/sites/default/files/documents/Status_of_COVID19_Vaccines_within_WHO_EUL-PQ_evaluation_process-16June2021_Final.pdf.

37. Shrotri M, Swinnen T, Kampmann B, Parker EPK. An interactive website tracking COVID-19 vaccine development. The Lancet Global health. 2021;9(5):e590-e2.

38. Kabamba Nzaji M, Kabamba Ngombe L, Ngoie Mwamba G, Banza Ndala DB, Mbidi Miema J, Luhata Lungoyo C, et al. Acceptability of Vaccination Against COVID-19 Among Healthcare Workers in the Democratic Republic of the Congo. Pragmatic and observational research. 2020;11:103-9.

39. Dror AA, Eisenbach N, Taiber S, Morozov NG, Mizrachi M, Zigron A, et al. Vaccine hesitancy: the next challenge in the fight against COVID-19. European journal of epidemiology. 2020;35(8):775-9.

40. Coustasse A, Kimble C, Maxik K. COVID-19 and Vaccine Hesitancy: A Challenge the United States Must Overcome. The Journal of ambulatory care management. 2021;44(1):71-5.

41. Khan YH, Mallhi TH, Alotaibi NH, Alzarea Al, Alanazi AS, Tanveer N, et al. Threat of COVID-19 Vaccine Hesitancy in Pakistan: The Need for Measures to Neutralize Misleading Narratives. Am J Trop 
Med Hyg. 2020;103(2):603-4.

42. Sallam M, Dababseh D, Eid H, Al-Mahzoum K, Al-Haidar A, Taim D, et al. High Rates of COVID-19 Vaccine Hesitancy and Its Association with Conspiracy Beliefs: A Study in Jordan and Kuwait among Other Arab Countries. Vaccines. 2021;9(1).

43. Sallam M, Dababseh D, Eid H, Hasan H, Taim D, Al-Mahzoum K, et al. Low COVID-19 Vaccine Acceptance Is Correlated with Conspiracy Beliefs among University Students in Jordan. Int J Environ Res Public Health. 2021;18(5).

44. Puri N, Coomes EA, Haghbayan H, Gunaratne K. Social media and vaccine hesitancy: new updates for the era of COVID-19 and globalized infectious diseases. Human vaccines \& immunotherapeutics. 2020;16(11):2586-93.

45. Wilson SL, Wiysonge C. Social media and vaccine hesitancy. BMJ global health. 2020;5(10).

46. Spaull N, Daniels RC, Ardington C, Benhura M, Bridgman G, Brophy T et al. Synthesis Report NIDSCRAM Wave 4. 2021. Available at URL: https://nicspaull.com/2021/05/12/nids-cram-wave-4-synthesisreport/.

47. Nguyen T, Henningsen KH, Brehaut JC, Hoe E, Wilson K. Acceptance of a pandemic influenza vaccine: a systematic review of surveys of the general public. Infection and drug resistance. 2011;4:197207.

48. Yaqub O, Castle-Clarke S, Sevdalis N, Chataway J. Attitudes to vaccination: a critical review. Soc Sci Med. 2014;112:1-11.

49. Salmon DA, Dudley MZ. It is time to get serious about vaccine confidence. Lancet. 2020;396(10255):870-1.

50. Shen SC, Dubey V. Addressing vaccine hesitancy: Clinical guidance for primary care physicians working with parents. Canadian family physician Medecin de famille canadien. 2019;65(3):175-81.

51. McClure CC, Cataldi JR, O'Leary ST. Vaccine Hesitancy: Where We Are and Where We Are Going. Clinical therapeutics. 2017;39(8):1550-62.

52. MacDonald NE. Vaccine hesitancy: Definition, scope and determinants. Vaccine. 2015;33(34):4161-4.

53. Schmid P, Rauber D, Betsch C, Lidolt G, Denker ML. Barriers of Influenza Vaccination Intention and Behavior - A Systematic Review of Influenza Vaccine Hesitancy, 2005 - 2016. PloS one. 2017;12(1):e0170550. 
54. Aguilar-Díaz Fdel C, Jiménez-Corona ME, Ponce-de-León-Rosales S. Influenza vaccine and healthcare workers. Archives of medical research. 2011;42(8):652-7.

55. Kraut A, Graff L, McLean D. Behavioral change with influenza vaccination: factors influencing increased uptake of the pandemic $\mathrm{H} 1 \mathrm{~N} 1$ versus seasonal influenza vaccine in health care personnel. Vaccine. 2011;29(46):8357-63.

56. Kaboli F, Astrakianakis G, Li G, Guzman J, Donovan T, Naus M. Influenza vaccination and intention to receive the pandemic $\mathrm{H} 1 \mathrm{~N} 1$ influenza vaccine among healthcare workers of British Columbia, Canada: a cross-sectional study. Infection control and hospital epidemiology. 2010;31(10):1017-24.

57. Seale H, Kaur R, Wang Q, Yang P, Zhang Y, Wang X, et al. Acceptance of a vaccine against pandemic influenza $A(H 1 N 1)$ virus amongst healthcare workers in Beijing, China. Vaccine. 2011;29(8):1605-10.

58. Schwarzinger M, Flicoteaux R, Cortarenoda S, Obadia Y, Moatti JP. Low acceptability of A/H1N1 pandemic vaccination in French adult population: did public health policy fuel public dissonance? PloS one. 2010;5(4):e10199.

59. Lau JT, Yeung NC, Choi KC, Cheng MY, Tsui HY, Griffiths S. Acceptability of A/H1N1 vaccination during the pandemic phase of influenza A/H1N1 in Hong Kong: a population-based cross-sectional survey. BMJ. 2009;339:b4164.

60. Sypsa V, Livanios T, Psichogiou M, Malliori M, Tsiodras S, Nikolakopoulos I, et al. Public perceptions in relation to the intention to receive pandemic influenza vaccination in a random population sample: evidence from a cross-sectional telephone survey. Euro surveillance. 2009;14(49).

61. de Figueiredo A, Karafillakis E, Larson HJ. State of Vaccine Confidence in the EU+UK. 2020. Available at URL: https://ec.europa.eu/health/sites/default/files/vaccination/docs/2020_confidence_rep_en.pdf.

62. de Figueiredo A, Simas C, Karafillakis E, Paterson P, Larson HJ. Mapping global trends in vaccine confidence and investigating barriers to vaccine uptake: a large-scale retrospective temporal modelling study. Lancet. 2020;396(10255):898-908.

63. Wiysonge CS, Ndwandwe D, Ryan J, Jaca A, Batouré O, Anya BM, et al. Vaccine hesitancy in the era of COVID-19: could lessons from the past help in divining the future? Human vaccines \& immunotherapeutics. 2021:1-3.

64. Saied SM, Saied EM, Kabbash IA, Abdo SAE. Vaccine hesitancy: Beliefs and barriers associated with COVID-19 vaccination among Egyptian medical students. Journal of medical virology. 2021;93(7):4280-91. 
65. Lazarus JV, Ratzan SC, Palayew A, Gostin LO, Larson HJ, Rabin K, et al. A global survey of potential acceptance of a COVID-19 vaccine. Nature medicine. 2021;27(2):225-8.

66. Sallam M. COVID-19 Vaccine Hesitancy Worldwide: A Concise Systematic Review of Vaccine Acceptance Rates. Vaccines. 2021;9(2).

67. Fares S, Elmnyer MM, Mohamed SS, Elsayed R. COVID-19 Vaccination Perception and Attitude among Healthcare Workers in Egypt. Journal of primary care \& community health. 2021;12:21501327211013303.

68. Kanyike AM, Olum R, Kajjimu J, Ojilong D, Akech GM, Nassozi DR, et al. Acceptance of the coronavirus disease-2019 vaccine among medical students in Uganda. Tropical medicine and health. 2021;49(1):37.

69. El-Elimat T, AbuAlSamen MM, Almomani BA, Al-Sawalha NA, Alali FQ. Acceptance and attitudes toward COVID-19 vaccines: A cross-sectional study from Jordan. PloS one. 2021;16(4):e0250555.

70. Abena PM, Decloedt EH, Bottieau E, Suleman F, Adejumo P, Sam-Agudu NA, et al. Chloroquine and Hydroxychloroquine for the Prevention or Treatment of COVID-19 in Africa: Caution for Inappropriate Offlabel Use in Healthcare Settings. Am J Trop Med Hyg. 2020;102(6):1184-8.

71. Haque M, Abubakar A, Ogunleye O, Sani I, Sefah I, Kurdi A, et al. Changes in availability, utilization, and prices of medicines and protection equipment for COVID-19 in an Urban population of Northern Nigeria. Journal of Research in Pharmacy Practice. 2021;10(1):17-22.

72. Godman B. Combating COVID-19: Lessons learnt particularly among developing countries and the implications. Bangladesh Journal of Medical Science, Special Issue on Covid19. 2020; S103-8.

73. Abubakar AR, Sani IH, Godman B, Kumar S, Islam S, Jahan I, et al. Systematic Review on the Therapeutic Options for COVID-19: Clinical Evidence of Drug Efficacy and Implications. Infection and drug resistance. 2020;13:4673-95.

74. WHO. COVID 19 Zambia. 22 June 2021. Available at URL: https://covid19.who.int/region/afro/country/zm.

75. Chabusha B. ZAMRA APPROVES 5 COVID-19 VACCINES FOR ZAMBIA. June 2021. Available at URL: https://zambiareports.com/2021/06/01/zamra-approves-5-covid-19-vaccines-zambia/.

76. Cadogan CA, Hughes CM. On the frontline against COVID-19: Community pharmacists' contribution during a public health crisis. Research in social \& administrative pharmacy. 2021;17(1):20325.

77. Aruru M, Truong HA, Clark S. Pharmacy Emergency Preparedness and Response (PEPR): a proposed framework for expanding pharmacy professionals' roles and contributions to emergency 
preparedness and response during the COVID-19 pandemic and beyond. Research in social \& administrative pharmacy. 2021;17(1):1967-77.

78. Hedima EW, Adeyemi MS, Ikunaiye NY. Community Pharmacists: On the frontline of health service against COVID-19 in LMICs. Research in social \& administrative pharmacy. 2021;17(1):1964-6.

79. Kayode OR, Babatunde OA, Adekunle O, Igbalajobi M, Abiodun AK. COVID-19 Vaccine Hesitancy: Maximising the Extending Roles of Community Pharmacists in Nigeria in Driving Behavioural Changes in Public Health Interventions. J Infect Dis Epidemiol. 2021; 7:205. doi.org/10.23937/2474-3658/1510205.

80. Mudenda S, Mukosha M, Mwila C, Saleem Z, Kalungia AC, Munkombwe D, et al. Impact of the coronavirus disease on the mental health and physical activity of pharmacy students at the University of Zambia: a cross-sectional study. International journal of basic and clinical pharmacology. 2021;10:324.

81. Bai W, Cai H, Liu S, Liu H, Qi H, Chen X, et al. Attitudes toward COVID-19 vaccines in Chinese college students. International journal of biological sciences. 2021;17(6):1469-75.

82. Qiao S, Friedman DB, Tam CC, Zeng C, Li X. Vaccine acceptance among college students in South Carolina: Do information sources and trust in information make a difference? medRxiv. 2020.

83. Lucia VC, Kelekar A, Afonso NM. COVID-19 vaccine hesitancy among medical students. Journal of public health. 2020.

84. Kelekar AK, Lucia VC, Afonso NM, Mascarenhas AK. COVID-19 vaccine acceptance and hesitancy among dental and medical students. Journal of the American Dental Association. 2021.

85. Barello S, Nania T, Dellafiore F, Graffigna G, Caruso R. 'Vaccine hesitancy' among university students in Italy during the COVID-19 pandemic. European journal of epidemiology. 2020;35(8):781-3.

86. Szmyd B, Bartoszek A, Karuga FF, Staniecka K, Błaszczyk M, Radek M. Medical Students and SARS-CoV-2 Vaccination: Attitude and Behaviors. Vaccines. 2021;9(2).

87. Kukreti S, Lu MY, Lin YH, Strong C, Lin CY, Ko NY, et al. Willingness of Taiwan's Healthcare Workers and Outpatients to Vaccinate against COVID-19 during a Period without Community Outbreaks. Vaccines. $2021 ; 9(3)$.

88. Papagiannis D, Rachiotis G, Malli F, Papathanasiou IV, Kotsiou O, Fradelos EC, et al. Acceptability of COVID-19 Vaccination among Greek Health Professionals. Vaccines. 2021;9(3).

89. Detoc M, Bruel S, Frappe P, Tardy B, Botelho-Nevers E, Gagneux-Brunon A. Intention to participate in a COVID-19 vaccine clinical trial and to get vaccinated against COVID-19 in France during the pandemic. Vaccine. 2020;38(45):7002-6. 
90. Malik AA, McFadden SM, Elharake J, Omer SB. Determinants of COVID-19 vaccine acceptance in the US. EClinicalMedicine. 2020;26:100495.

91. Patelarou E, Galanis P, Mechili EA, Argyriadi A, Argyriadis A, Asimakopoulou E, et al. Factors influencing nursing students' intention to accept COVID-19 vaccination: A pooled analysis of seven European countries. Nurse education today. 2021;104:105010.

92. Pugliese-Garcia M, Heyerdahl LW, Mwamba C, Nkwemu S, Chilengi R, Demolis R, et al. Factors influencing vaccine acceptance and hesitancy in three informal settlements in Lusaka, Zambia. Vaccine. 2018;36(37):5617-24. 